\title{
When Accessibility of Public Space Excludes. Shopping experience of people with vision impairments
}

\author{
leva Eskyté
}

University of Leeds, United Kingdom

School of Law, Centre for Law and Social Justice, Centre for Disability Studies

i.eskyte@leeds.ac.uk

\begin{abstract}
The United Nations Convention on the Rights of Persons with Disabilities (2006) recognises access to consumer goods and services in the mainstream private market as essential for full participation in society. Nevertheless, people with impairments rarely enjoy the same rights and consumer experience as non-disabled individuals. This paper argues that (in)accessibility of public space is an important factor shaping how accessible the private market is for people who do not 'fit' conventional norms and standards. It demonstrates how category-driven accessibility provisions in some geographical areas and not in others segregate disabled people within certain providers, create social and consumer isolation, and become a marker that accentuates difference and separation between disabled consumers who live in accessible districts, and the rest of the population. To illustrate the case, the paper uses empirical evidence from mystery shopping in retail outlets and qualitative interviews with people with vision impairments who live in the 'Blind district' in Lithuania. The district was developed by the Soviet Union (1949-1990) to boost people with vision impairments' participation in the socialist labour market economy.
\end{abstract}

Keywords: accessibility, public space, shopping, consumer, disability, vision impairments, Soviet Union

To cite this article:

Eskyté, I. (2019). When Accessibility of Public Space Excludes. Shopping experience of people with vision impairments, The Journal of Public Space, 4(4), 37-60, DOI I0.3289I/jps.v4i4.I 233

This article has been double blind peer reviewed and accepted for publication in The Journal of Public Space. 
Consumerism as a form religion (Varul, 2015) and political participation (Stolle et al., 2005), inherent part of citizenship (Miller, 2007, Guckian et al., 2017, Guthman et al., 20I6), means to shape and communicate identity (Hill, 20I I, Hamilton, 20I0) and social class (Lange and Meier, 2009), or source of pleasure and leisure (Stobart, 1998, Wearing et al., 20I3, Blackshaw, 20I3). Such and similar connotations are often used when talking about the relationship between retail markets and citizens in Western societies. Consumer participation has become a part of a modern reality (Bauman, 1988), and shopping in retail outlets is a natural activity of everyday life (Brusdal and Lavik, 2008). An individual's journey to a shop is often perceived as a spontaneous activity, which entails more than just a trip from $A$ to $B$ in order to procure a needed item. When traveling to shops, people make a number of decisions, such as to which shop to go, which route or transport means to choose, or when to go shopping. Public environment is one of the factors shaping the outcome of such and similar decisions, especially if one travel to shops as a pedestrian. For instance, some people consider directness (Hoogendoorn and Bovy, 2004, Hughes, 2002), shortest and quickest distance (Borgers and Timmermans, 2005, Seneviratne and Morrall, 1985) and safety of the route (Brown et al., 2007, Weinstein et al., 2008). Others tend to choose itineraries that are aesthetically pleasing, have nice architecture and a positive social environment (Brown et al., 2007), offer shelter from undesirable weather, have wide sidewalks and are more quiet than others (Guo, 2009, Guo and Ferreira, 2008, Guo and Loo, 20I3, Seneviratne and Morrall, 1985). Hoogendoorn and Bovy (2004:188) describe pedestrians as 'subjective utility maximisers', who found their pedestrian choice on maximal 'predicted utility of their efforts and walking'.

Public environment is aimed at providing 'average' citizens with comfort and convenience (Imrie, 1996, 2000, Freund, 200 I). Consequently, it creates visible and invisible obstacles (Hanson, 2004) for pedestrians who do not 'fit' predefined standards and norms. Steep and high curbs, uneven or crumbled sidewalks (Fänge et al., 2002, Matthews and Vujakovic, 1995), lack of ramps, various crossing-related barriers (Abir and Hoque, 20I I), insufficient lighting and limited places to rest (Rosenberg et al., 20I2) often impede into people with mobility impairments and wheelchair users' experiences (Eskytè, 2019). Limited availability of audible traffic lights (Ivanchenko et al., 2010), drivers' ignorance of white or long cane users (Eskytè, 2014, 2019), lack of directing information in Braille and alternative formats (Crandall et al., 200I) and limited installation of integrative tactile paths (Imrie, 1996) are some of the reasons that prevent people with vision impairments from independent, stress-free and safe interaction in public space. Likewise, the lack of visual aids and information signs (Imrie, 1996) often make people with hearing impairments' migration in neighbourhoods and cities they live in challenging. On the other hand, peer-interaction- related concerns such as safety and lack of support often shape people' with learning difficulties and cognitive impairments' pedestrian choices and contribute to the exclusion from interaction and participation in public space (Bertoli et al., 20I I, McClimens et al., 20I4).

Visible and invisible obstacles in the public environment (Hanson, 2004) that cause discomfort, restriction and exclusion (Imrie and Kumar, 1998) emerge due to ableism 'ideas practices, institutions, and social relations that presume ablebodiedness, and by doing so, construct persons with disabilities as marginalised, oppressed, and largely 
invisible 'others" (Chouinard, 1997:380). Goodley (2014: 2I) suggests that "ableism's psychological, social, economic, cultural character normatively privileges ablebodiedness; promotes smooth forms of personhood and smooth health; creates space fit for normative citizens; encourages an institutional bias towards autonomous, independent bodies; and lends support to economic and material dependence on neoliberal and hyper-capitalist forms of production." The philosophy has had a great effect on the development of built environment. According to Relph (1981:196), 'modern landscapes seem to be designed for forty-year-old healthy males driving cars'. Consequently, all Western (Imrie, 1998) and non-Western cities (Freund, 200I) are created by and for non-disabled society members, and only a limited variety of individuals may use and freely function in the public environment (Freund, 200I). The ethos of ableism in public space is complemented by auto-centred systems and developments (Imrie, 20I2, Moody and Melia, 20I4). Roads, streets, street crossings and other elements are shaped around motorised vehicles (Hamilton-Baillie, 2008, Guo and Ferreira, 2008, Freund and Martin, 1997). Even the introduction of a shared space concept is delivering little, if not counterproductive, benefits for pedestrians, especially to those who do not 'fit' the norm (Imrie, 2012, Karndacharuk et al., 2013, Kaparias et al., 20I3, Beitel et al., 20I8, Essa et al., 20I8). Poor design and inadequate provisions create pedestrian-vehicle conflict (Kaparias et al., 2013, Vedagiri and Kadali, 2016) with more severe implications for disabled pedestrians (Imrie, 2012, Eskyte, 2015, 20I9). People with impairments often experience spatial isolation (Kitchin, 1998), are located within an officially defined travelling timeframe (Freund, 200I) and their spatial behaviour is restricted. Current approach to and practice of developing public space create 'no go' areas (Kitchin, 1998:346) that mirror modern ideals for aesthetics (Imrie, 1998), same-able-bodied understanding (Matthews and Vujakovic, 1995) and prioritise non-disabled wealthy males (Relph, 198I). This conditions disabled people's travel choice and freedom as well as restrict their pedestrian participation.

Since interaction in public space and pedestrian experience is an important part of shopping (Eskytè, 2019), it seems reasonable to question the impact of public space on disabled consumers' participation. Nevertheless, before engaging in this discussion, some clarity on how disability is understood in this paper is necessary. I adopt the social model perspective that positions 'impairment' as a feature or physical limitation of particular individuals (Oliver, 1983, 1996), and 'disability' as something imposed on top of people's impairments, by the way they are 'unnecessarily isolated and excluded from full participation in society. Disabled people are therefore an oppressed group in society. To understand this it is necessary to grasp the distinction between the... impairment and the social situation, called 'disability', of people with such impairment' (UPIAS, 1976:3-4). According to Oliver (1983:23), the understanding of impairment and disability from the social model perspective 'involves nothing more or less fundamental than a switch away from focusing on the physical limitations of particular individuals to the way the physical and social environments impose limitations upon certain groups or categories of people'. In such a context, society's reaction to impairment (Morris, 1993), unequal power relations between disabled and non-disabled people (Barnes and Mercer, 2003, Campbell and Oliver, 1996) and social barriers and prejudice (Shakespeare, 1996) are key reasons for exclusion, marginalisation and oppression. 
Shifting the attention back to how public space shape disabled people's shopping and customer participation, the United Nations (UN) Convention on the Rights of Persons with Disabilities (CRPD) (2006) recognizes access to consumer goods and services in the mainstream private market as essential for full participation in the society (art. 9.2b). Alongside the call for markets accessibility, the Treaty requires taking appropriate measures to ensure that disabled people have access, on equal basis with others, to buildings, roads, transportation and other indoor and outdoor facilities (art. 9.2a). Nevertheless, academic, policy and advocacy communities provide ongoing evidence of inaccessibility of public space and its disabling impact on lives of people with impairments. While a number of studies address disabled people's interaction in public space (Butler and Bowlby, 1997, Kitchin, 1998, Imrie and Imrie, 1996) or shopping experience (Baker, 2006, Baker et al., 2007, Baker et al., 200I, Kaufman-Scarborough, 1999, Kaufman-Scarborough, 200I, Kaufman-Scarborough, 2016, Bashiti and Rahim, 2016), the two dimensions are rarely linked together. In fact, there is hardly any research that goes beyond issues such as physical barriers in public buildings, inaccessibility of indoor retail premises, or the attitude of shop assistants. For instance, what do we know about how accessibility of streets and pavements shape people with impairments' decisions where to purchase? How pedestrian density impact disabled people's shopping time and duration? How maintenance of streets and sidewalks is related to their engagement in customer participation? How accessibility of public space impact willingness to pay and how it is related to customer loyalty?

We know precious little about the way accessibility of public space shape people with impairments' shopping and customer participation. The aim of this article is to add to the issue of matter. To be precise, shopping experience of people with vision impairments is used as a case study to demonstrate that fragmented accessibility provisions or provision of accessibility only in particular geographical spaces construct disabled people's vulnerability, exclusion and inequality in the mainstream retail market. To this end, the paper draws on an international qualitative study that focuses on an accessible shopping chain in the EU single market. It extracts accounts of people with vision impairments and Blind people who live in a 'Blind district' in city X, Lithuania. The focus on this particular group is two-fold. First, people who live in the 'Blind district' often are a 'silent' group of disabled people's population. Their experiences are often approached and interpreted in the context of accounts of disabled people who live in different parts of the city. Leading a life in a neighbourhood which was designed for a particular group might be significantly different from living in a 'mainstream' neighbourhood or district. Hence, it is important to focus on how public space and build environment of the 'Blind district' shape people with vision impairments' interaction with and participation in society. Second, while socialist city planning is well discussed in literature, there is little known how former development of build environment aimed at planned economy and participation in the labour market shapes people's current interaction with and in a city of a consumerist society. Hence, the paper adopts the social model perspective and looks at how former soviet city developments shape current customer participation of people with vision impairments. First, literature concerning socialist city planning is reviewed. Then light is shed on how built environment and public space used to be developed in areas specially designated for people with vision impairments. Then the design and broader study, which looks at customer interaction in public space as a part of an accessible shopping chain, is 
introduced. The empirical discussion explores how former development of public space either 'lock in' or 'lock out' people with vision impairments from shopping and broader engagement with private providers. This is followed by a discussion on how poor maintenance of public space contributes to the exclusion. The paper concludes with a discussion of the findings and implications for future research.

\section{Socialist city planning}

Industrialisation, planned economy and heavy industry provided the foundation for the socialist city planning. Urbanisation, labour concentration in cities and increased people's migration from rural to urban areas required a particular planning (Grava, 1993). Fisher (1962: 25I) describes this as an 'active planning, that is, the active projection of economic activities (allocation of resources, distribution of income) as opposed to the passive forecasting of spontaneous development'. The city was positioned as a fundamental element of the supreme communist community, representing centralisation, standardisation and uniformity of social organisation across the Union (Thomas, 1978, Fisher, 1962, Bertaud and Renaud, 1997, Temelová et al., 20II). Most importantly, city aimed to serve for the government's interests (Grava, 1993) and was concerned 'with the location and distribution of economic productive forces: industry, power, and transportation' (Fisher, 1962:252).

Microrayons are the best example of city planning premised on the achievement of the socialist goals (Clapham, 1995, Kostinskiy, 200I). Commonly described as 'superblocks followed the high-rise buildings in a park' (Grava, 1993:13) they provided a high number of affordable accommodation (Permain and Roberts, 20I2) and the impression of 'sameness' and 'normality'. While some of the neighbourhoods were well equipped with nurseries and schools, the majority had weak social infrastructure, health care and recreational facilities, and often were unsafe (Grava, 1993, Temelová et al., 20I I, Černič Mali et al., 2003). The design of microrayons and flats was highly standardised aiming to introduce a classless society and to effectively maximise limited resources (Fisher, 1962). On the one hand, the goal of resource maximisation has been partly achieved in some parts of the Soviet Union (Fisher, 1962, Alexandrova et al., 2004, Temelová et al., $20 \mathrm{II})$. On the other hand, instead of creating a classless society and introducing the same conditions to the residents, it created division, spatial isolation and reinforced ghettoization of some groups of the population. For instance, Fisher (1962) reports the division of Polish population based on their marital status or number of children. Alexandrova et al. (2004) provide some evidence suggesting that individuals belonging to different economic classes used to be located in different parts of city Tomsk, Siberia. Similarly, professionals with higher education and highly demanded skills that were needed for effective work in factories used to get flats in neighbourhoods close to the workplace (Fisher, 1962) and often had better accommodations (Sasnovy, 1959, Kulu, 2003). Contrarily, people with the lowest education status usually lived in the worst quality housing and in the neighbourhoods with limited possibilities for spatial and economic mobility (Dangschat, 1987). In a similar vein, ethnic minority groups were usually accommodated in remote areas and in neighbourhoods far away from city centre and local residents. As an example, aiming to secure more prestigious neighbourhoods for native Russians (Temelová et al., 20II) and to ensure demographic control (Fisher, 
1962) ethnic minority groups used to be accommodated in the city offside far away from local population (Ladanyi, 1993). Poor transportation and undeveloped infrastructure were often used as a means to cut off 'undesirable' groups from accessing and interacting in the city (Alexandrova et al., 2004) and to make them an invisible part of the population. Such practices define individuals and their experiences, ascribe them with a certain social status and position, signify their difference and deviation from those who are perceived as 'normal' and expected citizens as well as reinforce oppressive social relationship between society members (Imrie, 1996, Laws, 1994). Drawing on Wacquant's (1998) work, Bauman (200I) notes that such practices physically and morally distance segregated groups; strengthen homogeneity among the group members and contrast them with heterogeneous mass outside the 'ghetto'.

The politics of exclusion and social distancing (Phillips, 2009) required to make people with impairments invisible and hide them from the 'non-invalid' population (Dunn and Dunn, 1989, Fefolof, 1989). Contrary to ethnic minority groups, spatial isolation of disabled people used to be achieved either by lodging them in institutions (Phillips, 2009, Tobis, 2000) or by providing special accommodations in certain areas and not in others. For instance, Temelová et al. (201 I:1830) reports that during Soviet times disabled individuals in the Czech Republic were gathered into a special neighbourhood in Kročehlavy, where they were accommodated in ' 255 municipal dwellings concentrated in a long prefabricated blocks'. Research conducted by Sasnovy (1959) and Morton (1980) suggest that individuals who acquired impairments in the World War Two and 'invalids' with particular diseases often were provided with better housing conditions, accommodated in special parts of the microrayons and were entitled to various housing-related privileges (Madison, 1989). However, despite relatively better conditions, the neighbourhoods often were characterised by stigmatisation, limited access to and low level of education and high level of unemployment (Temelová et al., $20 \mathrm{II}$ ). On the other hand, aiming to boost planned economy and exploit all available 'resources', the Soviet Union used to develop neighbourhoods and labour market infrastructure for specific groups of people. People with vision impairments and Blind people was one of the groups to whom special neighbourhoods with certain labour market facilities had been developed across the Union. Often called 'Blind districts' the neighbourhoods had special public space and built environment arrangements aimed at achieving labour market and planned economy goals.

\section{The 'Blind district'}

Lithuania was occupied by the Soviet Union several times. The longest and most recent period lasted approximately 50 years (1940-1990). Like other Soviet countries, Lithuania went through the majority of processes typical to the Union, including the socialist city planning, including the development of neighbourhoods aimed at harnessing people with vision impairments as a labour force. While academic literature on the topic is scarce, archives of organisations for people with vision impairments suggest that usually this group of population was not dispersed throughout cities but used to be accommodated in certain districts. These were often located near schools or workplaces adjusted to the needs of people with vision impairments, as they did not 'fit' either mainstream education or labour market (Dangschat, 1987, Grava, 1993, Madison, 1989).

The Soviet government was the driving force behind the practice of segregation and was 
supported by activists with vision impairments, who emphasised people's integration in the labour market. The statement made by Avižonis P., one of the leaders of Blind Lithuanians community at that time, illustrates the logic: 'smart social policy does not require benefits or alms, but the development of residual skills and agency for productive work' (LASS, n/a). The state and civil society invested in the provision of accommodated work places, enabling people with vision impairments to actively and efficiently contribute to socialist economy goals. The majority of taken actions were successful and production grew rapidly. Consequently, in 1958 the government released an official decision to start a systemic development and building of block-houses for people with vision impairments in the neighbourhoods close to the nurseries, schools and factories that were already adjusted for their education and work. During thirty years (19581998) the Union of Blind Lithuanians has built around 100,000 square metres of industrial, domestic and cultural purpose buildings, and more than three thousand flats and other objects, usually located around the factories accessible to people with vision impairments (LASS, n/a).

Accessible work places and flats used to be located in certain districts, usually microrayons, and not dispersed across a city. Consequently, people with vision impairments were often isolated from participation in education and labour market outside the districts they lived in (Eskyte, 2014). On the one hand, systematic provisions of needed adjustments and accessibility in particular geographical locations were employed as a tool to 'erase' people with vision impairments from the mainstream population as they did not 'fit' an ideal image of a 'perfect' Soviet citizen. On the other hand, such arrangements enabled people with vision impairments to better meet imposed expectations of a productive labour force, and to efficiently contribute to the wealth of the Soviet Union and socialist economy.

Districts developed for people with vision impairments shared some similarities as well as differences with districts for the non-disabled mainstream population. With regard to similarities, aiming to provide an illusion of sameness and classless society, housing for workers with vision impairments tended to conform to building standards of a particular town or city. As an example, typical microryaons and block-houses in small towns, such as Švekšna, were smaller compared to the developments in bigger cities such as Kaunas or Vilnius (LASS, n/a). In addition, at the first sight microrayons for workers with and without vision impairments used to look identical (Fisher, 1962) and the construction in both types of neighbourhood was fast and careless (Temelová et al., $20 \mathrm{II}$ ), causing challenges and inconvenience for the inhabitants.

With regard to differences, the most significant one was a pedestrian underpass. The overview of the LASS history (LASS, n/a) suggests that in 1975 in one of the districts where the majority of residents had vision impairments and a number of adjusted education and work setting operated, a pedestrian underpass was built. Later a number of pedestrian underpasses were built across the country, but only where a number of people with vision impairments is high. The development was usually jointly financed by the government and the Lithuanian Blind People's Union. The underpasses were perceived as a way to release individuals with vision impairments from crossing busy and intense streets and to provide a safer environment and better conditions for their journey from home to factories, libraries, shops and bus stops (LASS, n/a). While Alexandrova et al. (2004) demonstrate how limited or poor provision of transport 
infrastructure and urban facilities were used as a means to isolate 'problematic' groups in 'special' and remote neighbourhoods; the provision of facilities that to some extent meet people with vision impairments' accessibility needs was used to 'keep' them in particular geographical spaces. While the goal behind the spatial isolation of the 'undesirable' groups was their disconnection from and absence in the rest of the city (Alexandrova et al., 2004), people with vision impairments' spatial segregation employed as one of the ways to boost their efficiency in and contribution to the socialist economy (Fisher, 1962) and to keep them invisible in a broader context of the society (Phillips, 2009).

The provision of safer and more accessible environment and public space in certain districts and not across the city diminished people with vision impairments' free and independent participation in labour market and community, and perpetuated their ghettoisation. Segregated neighbourhoods gradually acquired the 'Blind district' name. This has embodied the discourse and practice of exclusion, stigmatisation and otherness. The 'Blind district' name remains entrenched by and is communicated via public artefacts such as bus stops or street names, and is alive in disabled and nondisabled individuals' every day vocabularies (Eskyte, 20I5). While due to recent changes in the real estate market and social policy people with vision impairments get more dispersed across cities, a great number of them or their family members with vision impairments remain in the initial districts. This is because several work places and education institutions as well as private retailers offering needed adjustments are available in the neighbourhoods and not outside them. Similarly, while the development of the rest of the city is founded on ablest assumptions (Eskytè, 2019), certain accessibility provisions in built environment are present in the district this not being the case outside it.

\section{Researching consumer participation in the context of built environment and public space}

International qualitative study combined mystery shopping and semi-structured interviews with disabled consumers (Lithuania and the UK) with semi-structured interviews with and observations of civil society and private market players (national (Lithuania, the UK) and international (EU)). The accounts shared by disabled consumers with vision impairments who live in one of the 'Blind districts' in Lithuania provide the foundation for this article. The qualitative data is used to demonstrate how provision of accessibility only in certain parts of a city and absence of a holistic approach construct disabled people's spatial isolation in the mainstream private market shape their 'shopping map' and prevent broader engagement with the city they live in.

\section{Mystery shopping and qualitative interviews}

Mystery shopping and qualitative interviews were employed to investigate consumers with vision impairments' experiences and to demonstrate how provision of accessibility in some parts of a city and a lack of an over-arching approach shape the 'shopping map' of people with vision impairments' and limit their consumer participation in the mainstream private market. 
Mystery shopping is a form of participant observation where the researcher interacts with the research participants being observed and stems from the field of cultural anthropology (Miller, 1998). The method is widely used in marketing (Miller, 1998, Collins et al., 2017, Yaoyuneyong et al., 2018) research and offers a possibility to identify different factors in the service delivery process (Jacob et al., 2018, Liu, 2015) and their effect on natural conditions (Grove and Fisk, 1992). It allows to test whether disabled consumers are treated equally or are discriminated against (Morrall, 1994, Wiele et al., 2005, Eskytè, 2019) and to address discrepancies between real and reported consumer and seller behaviour (Friedrichs et al., 1975, Kehagias et al., 20I I). The observational data was supplemented by accounts shared in semi-structured oneto-one interviews. This qualitative approach allowed identifying consumer experiences and the meanings that people ascribe to shopping process and outcomes (Gray, 2009). It captured participants' perceptions and opinions about their experiences on the way to shops, and revealed more detailed responses and clarifications of the reasons and motives (Arksey and Knight, 1999) behind choosing certain routes to certain shops (Eskytè, 2019). Accessibility of the research tools and communication means was highly important. The participants could choose from several accessible formats they wish to receive the information in. These included large print, easy read, easy read with pictures both in hard copy and electronic format. Techniques such as simple words and pictures, short sentences, asking one question at a time, and rephrasing questions were used. Self-directed reflections by the interviewee (Rodgers 1999) were also encouraged. The interview guide included a number of questions addressing key stages of an accessible shopping chain (Eskyte 2019). The questions were followed by a list of probes and observation data from the mystery shopping. This allowed for explaining the questions (Bryman 2012) and ensured further elaboration and clarity of the provided accounts (Gray 2009; Ruane 2005).

In total thirty-eight people with mobility, vision, hearing and cognitive impairments and mental health conditions (UK and Lithuania) participated in the study. The discussion in the paper is founded on the data extracted from seven mystery shopping outings and interviews with people with different range of vision impairments who live in the 'Blind district' in city $X$, Lithuania. All informants were white Lithuanians, whose age varied between $30+$ and $65+$. They were of different gender, education and socio-economic status, as well as shared similar and unique consumer experience. All informants lived in flats in block-houses in the same microrayon, specially designed by the Soviet Union for people with vision impairments. One participant lived alone, while others lived with partners or family members. Small but diverse cohort of the informants represented and acted as 'information rich cases' and enabled to 'learn a great deal about matters of importance' (Patton, 1990: 181) for this particular group.

The study was underpinned by the social model of disability. It positions social, cultural, historical and capitalist market structures and other external factors as keydeterminants behind exclusion and marginalisation of people with impairments as society members (Barnes and Mercer, 1996, Barnes and Mercer, 2003, Barnes and Mercer, 2005, Imrie, 2013, Priestley et al., 2007, Campbell and Oliver, 1996, Oliver, 2009, Oliver, 1990, Oliver, 1994). Consequently, medical diagnoses and impairmentrelated peculiarities were not in the interest of this study. For the data analysis a thematic approach was adopted. It involved "careful reading and re-reading" (Rice and 
Ezzy 1999: 258) of research material aiming to identify the main themes. Alongside the pattern identification within the data (Fereday and Muir- Cochrane 2008), individual or unique cases were noted down. The interviews were repeatedly read, aiming to find commonalities or contradictions among the unique cases.

In order to demonstrate how provision of accessibility in some geographical locations and their lack or absence throughout the city creates people with vision impairments' spatial exclusion and elimination from equal customer choice and participation, the discussion of the empirical data is divided into three parts. First, the focus is on how accessibility provisions in particular geographical spaces 'lock people in' certain parts of the private market. The discussion then draws on how inaccessible city design "lock people with vision impairments out' from broader participation in and interaction with private retailers. Finally, the role of maintenance of public spaces in shaping experiences of consumers with vision impairments is addressed.

\section{'Locked in' by urban design}

Accessibility provisions and adjustments available in the 'Blind district' have a double effect on people with vision impairments' consumer participation and experience. On the one hand, they provide safer and less stressful access to certain providers, enable easier navigation in the neighbourhood and provide more independency. On the other hand, the provisions shape people's choices and decisions where to shop. Participants' narratives suggested that food, domestic, cleaning and IT products are usually purchased within the district. To illustrate, Rolandas (male, age 4I-64) said:

When I go to or from work, in my street there are few kiosks, so there I buy meat, milk, raw meat, and prepared food. I do not have any problems there. And it is very easy to reach the place as it is on my way home. Here, in this shop [another shop on the same street] I can buy everything that I need for my computer. It is easy to reach these shops as they are here.

(Rolandas, male, age 4I-64)

Similar account was shared by Ramune who buys products for everyday cooking or cleaning from 'local' businesses, and travels to shops outside the district only for 'special' items:

I go somewhere else only if I need something special that I cannot find here. For instance, when I need abstergents that I like I take $a$ bus and go there.

(Ramune, female, age 18-40)

The narrative of 'usual'/'local' versus 'special' shopping was common in other participants' accounts. They often linked 'usual' shopping with shopping within the 'Blind district' that typically happens every day and does not require special planning or arrangements. Meanwhile, 'special' shopping was usually linked with the acquisition of items that are unavailable at the retailers operating in the district. It is important to note that the foundation for the distinction was not so much product features- related, as it was linked to the providers' geographical location, and the journey to shops outside the district. It seemed that accessibility within the district and a lack or insufficiency of it in 
other parts of the city form values and complexity that customers with vision impairments ascribe to shopping. While non-disabled population usually value and categorise consumer experience because of product or service delivery characteristics (Campbell, 1997, Carrigan et al., 2004, Mittal and Kamakura, 200 I, Otieno et al., 2005, Torres et al., 200I, Yuksel, 2004), people with vision impairments whose consumer mobility is shaped by public environment (Eskytè, 2014, 2015, 2019) seem to emphasise geographical location of private providers and the experience of reaching them. They position these as important factors shaping their attitudes toward and ascribed value to shopping in certain locations.

Similarly, Juozas referred to 'serious' shopping. He identified shopping as 'serious' when he needs to travel to other parts of the city and for this reason is usually accompanied by his daughter:

If we need to do a serious shopping and to go somewhere else, I always go with my daughter. She is the boss on that. But you know... sometimes I don't mind to pay more, if it means that I can go and buy a packet of cigarettes on my own. (Juozas, male, age 4l-64)

It seems that due to accessibility of and familiarity with the 'Blind district' some participants equalise consumer experience outside it with a burden or additional effort that is not directly related to acquisition of goods and services. On the other hand, their accounts about shopping in the neighbourhood were accompanied by narratives of comfort, confidence and independence. Juozas' reference to a higher price that he sometimes needs to pay for certain products sold by the providers operating in the 'Blind district' was not an exception as well as his willingness to do this was common in other informants' narratives. The majority of the participants seemed to be willing to pay more in order to secure independence when travelling to shops. Hence, while nondisabled shoppers' eagerness to pay a higher price is often interpreted as an evidence of consumer satisfaction with goods, services and service delivery (Baker and Crompton, 2000), for shoppers with vision impairments accessible location of retail outlets is an important factor shaping their loyalty and limited objection to pay more.

Accessibility provisions in the 'Blind district' shape people with vision impairments' involvement with and loyalty not only to sellers but also to service providers. Shared accounts suggested a variety of services that are used mainly because of their accessible location. All informants expressed their preference to approach shoemaker, and leisure and finance service providers that are in the neighbourhood and are easy to access by the pedestrian underpass. For instance, Juozas noted that he prefers to have his shoes fixed by the 'local' shoemaker even though the price is higher than in some other places outside the 'Blind district':

Maybe the price is not the best, but it is the most convenient place and I can go there without any major advance planning.

(Juozas, male, age 4I-64)

In a similar vein, llona (female, $4 I-64$ ) noted that she is aware of a number of sport clubs outside the district that offer various services and may better meet her needs. 
However, she prefers going to the 'local' sport club as this saves her time and does not cause additional stress:

I know that in the $Z$ neighbourhood there is a sport club, which apparently is very good and provides lots of additional services such as massage and different spa treatments. My cousin goes there and she is really happy. I go there occasionally, usually on the weekends, when I have more free time. Even though I could afford the price, I can't afford the time and stress that I feel when I go to the city. You see, I have too much this kind of experience in my daily life and try to avoid it as much as I can.

Similar reasoning for which provider of goods and services to approach was evident in the majority of the informants' accounts. This suggests that accessibility of built environment and public space plays an important role in shaping people with vision impairments' consumer choice and experience. They seem to choose goods and service providers that are in accessible locations, and are easy to reach. Respectively, private market actors who operate in inaccessible locations are avoided. Accessibility of the 'Blind district' shape the factors according to which people with vision impairments measure and value providers and form attitudes towards price. In other words, in environments that are accessible 'islands' in inaccessible cities, certain market principles are reshaped as in the context of making consumer choice and decision on a payable price, quality of goods and services and service provision are

\section{'Locked out' by urban design}

Inaccessibility of the city outside the 'Blind district' further prevents people with vision impairments from exploring a bigger map of the private market. Discussing their consumer experiences outside the district, the participants constantly referred to obstacles such as crumbling pavements, curbs, similarity of street and sidewalk colours, and inappropriate maintenance of the built environment among others. Even though similar obstacles are present in the 'Blind district', due to limited possibility to travel, individuals become aware of and familiar with these barriers. Consequently, they develop coping strategies and have better opportunities to actively engage in shopping and other kinds of consumer activities. In the meantime, activities outside the 'Blind district' are often associated with challenges, uncertainty and special preparation. To illustrate, Juozas noted:

You can go there [to the city outside the district], but you will face a lot of challenges. You have to have a special navigating system or some kind of special plan or a map, but still you can't be sure that you will not fall into a pit or hit the pillar or face any other obstacles that were not there yesterday.

(Juozas, male, age 4I-64)

Other participants shared similar concerns and this suggests that the city outside the district is often associated with obstacles, challenges, dependency and potential harm. Such practice indirectly shapes people with vision impairments' ghettoisation in the 'Blind district', and may lead to spatial division between 'here' and 'there'. In such a context inaccessible city landscape becomes a spatial marker that generates 
exclusionary practice (Imrie, 1996) and signifies a difference between individuals as consumers and citizens operating in the two kinds of environment. Insufficient accessibility provisions outside the neighbourhood reinforce social inequality, disablist social values and continue boosting people with impairments' marginalisation. Physical isolation not only limits individuals' mobility and denies rights but also erases the opportunity for people with and without vision impairments to interact with and become aware of each other.

Research results from a broader study of the project suggest that consumers with vision impairments who live in other parts of the city usually spend between fifteen to thirtyfive minutes traveling to retail outlets. On the other hand, individuals who live in the 'Blind district' usually reach chosen shops in three to seven minutes. In spending less time traveling to a shop, people who live in the discussed district have less time and opportunities to engage into pedestrian or public transport user roles and activities, social networks and communities, and to acquire consumer information provided in public spaces. Finkelstein (1994: 2-3) notes that 'travel does not just mean moving from one place to another. It also entails seeing the world from a particular viewpoint and, more importantly, sharing common experiences with fellow citizens'. Having a restricted access to the city outside the district and fewer possibilities to freely travel and operate within it, people with vision impairments who live in the 'Blind district' may acquire different experiences and interpretations of the world to these of individuals and consumers operating outside it.

Access to and participation in the rest of the city is further limited by an insufficient provision of audible traffic lights. All informants noted that while there are few audible traffic lights in the district, the situation in other parts of the city is opposite. As an example, Ramune said:

How do I cross the street in general in the city? I look for traffic lights. If there were audible traffic lights it would be much easier.

(Ramune, female, age 18-40)

Similarly, Rolandas noted that in the 'Blind district' he is independent and feels safe as he can cross intense traffic streets by using either the pedestrian underpass or audible traffic lights. However, this is not the case in other parts of the city. To illustrate, he said:

Drivers do not care whether you are Blind or not. Usually they do not slow down even if they see your white stick. And then there are no audible traffic lights and sometimes there are no traffic lights at all, so it gets a bit tricky. Then I usually trust my hearing. Firstly I listen to cars 'whizzing' on my left, then rush and stop somewhere in the middle of the street and listen to cars 'whizzing' on my right. It is dangerous, especially in mornings, and I never know how my gamble will finish, but sometimes or I would say often, this is the only way to cross the street (Rolandas, male, age 18-40).

Audible traffic lights in the 'Blind district' enable people with vision impairments to be more independent and mobile citizens and consumers. Additionally to providing more 
opportunities for participation in the social life together with their non-disabled peers, accessibility provisions such as audible traffic lights seem to distract the attention from impairment and erase culturally and socially formed difference between disabled and non-disabled individuals. As an example, Juozas said:

These beeping traffic lights are forever here and if some of them sometimes stop working than we realize how helpful they are. When they work there are no problems: you can reach any shop, bus stops, friends and work place without thinking how to cross the street and to not be hit by a or wait for people, who you could follow when they cross the street. Audible traffic lights that we have here not only provide more safety but also an opportunity not to be different from others. Then other people who do not have vision impairments do not notice us because of our blindness and we are more or less equals.

(Juozas, male, age 4I-64)

Recent policy instruments could have opened up the door to the rest of the city for people with vision impairments. However, they lack a continuum approach to accessibility and may further reinforce spatial isolation. Specifically, the Rules for Mounting Pedestrian Crosswalks in Lithuania (LRV, 20I2) do not specifically refer to the provision of audible traffic lights. In addition, although Rubric IV of the aforementioned rules oblige to consider disabled people's needs (section 59) and provide basic adjustments for mounting pedestrian crossings, sections 6I, 62 and 65 establish that different accessibility elements should be set only 'where there is a flow of disabled people'. Since Lithuania has regained independency less than thirty years ago, it is not surprising that areas which under the soviet regimen were used as means to isolate people with impairments from the rest of society have remained inhabited by disabled people more densely than other parts of the city. Consequently, the 'flow of disabled people' in such areas is bigger than elsewhere. The application of quantitative measures instead of quality- oriented criteria maintains exclusion and spatial and social division practices established by the Soviet Union. Provision of accessibility in some areas and a lack of over-arching approach continue restricting individuals' participation in social and political life and restrain their spatial and economic mobility. In addition, in associating audible traffic lights with disabled people, the policy instrument disadvantages other groups (eg children, parents with young children, people using mobile phones) who may benefit from such devices but live in districts where 'the flow of disabled people' is not big enough.

\section{'Locked in' by poor maintenance of public space}

The 'Blind district' seems to be more accessible than the rest of the city. However, improper maintenance of public space in the neighbourhood exclude some people with vision impairments and especially older, from shopping and other types of consumer experience. For instance, Hilda noted that she goes shopping only in late spring and summer because then various build environment elements and barriers are more visible than they are in autumn or winter. The female then becomes an indirect shopper, whose consumer role is exercised on behalf of her by a third party: 
I give her [the daughter] the list of products that I need and she buys. It is so great that she lives not far away from my home, so I do not need to struggle in the street (Hilda, female, age 65+).

This suggests that even within the area that was intentionally designed to accommodate people with vision impairments, some individuals do face barriers. In Hilda's case, poor street lighting in the dark seasons of the year eliminates her from shopping and converts into a dependent consumer, whose shopping time and product choice depend on social or support networks. Being isolated from shopping Hilda and other individuals dealing with similar situations are prevented from active and passive socialising (Graham et al., 1991), embedment into social networks and communities (Miller et al., 1998, Eskytè, 2019), and experience of shopping as leisure activity (Miller and Kim, 1999). In addition, Hilda decides only the list of products; and the brand, package and choosing process itself is decided and experienced by others. In such a context, poor maintenance of built environment plays an important role in diminishing her consumer control and provides an illusion, that the purchase is an outcome of her own decision (Kishi, 1988). Juozas (male, age 4I-64) addressed similar challenges caused by improper maintenance of the district in winter. He noted that since the snow changes 'the scenery of pavement' and it gets easier to get lost, a failure to remove snow and ice from pedestrian sidewalks decreases his and other individuals with vision impairments' control and mobility in public space, may cause physical injuries as well as change shopping and consumption practices and habits. This suggests that accessibility should not be understood only as physical environment or its design. Contrary, it should be approached in its full complexity. A failure to adopt an over-arching approach is likely to transform accessible environments and spaces into inaccessible and unusable, and eliminate disabled people's freedom and rights that are taken for granted by nondisabled society members.

Due to accessibility of the district and inaccessibility of the rest of the city the informants are well familiar with the neighbourhood. This shapes their resilience and coping strategies that enable overcoming the obstacles. It was evident that the most common practice is to choose familiar and 'tested' routes. As an example, Hilda said:

I have my summer way to the shop, to the bus stop and to the Centre. I know them by heart, and this is the only reason why I haven't broken my neck yet.

(Hilda, female, age 65+)

A similar account was shared by Ramune:

Wherever I go, I have my itineraries, which are secure and I know that they will not put me in trouble.

(Ramune, female, age 18-40)

While learnt routes and itineraries enable the informants to feel more secure and free, they limit their consumer mobility. The usage of the same and learnt traveling routes dominates novelty and spontaneous shopping choices and decisions, and shape the pattern of acquiring goods and services from the same providers. 


\section{Conclusion}

The accounts shared by the research participants towards their consumer experience in the 'Blind district' are broadly illustrative of how provisions of accessibility in certain spaces but not in others may create exclusion and segregation. Disabled people's movement positions accessibility as a precondition for people with impairments' independent life (CRPD, art. 19) and full and equal participation in society (CRPD, art. 9). Limited or absent access to the built environment, to transportation, and to other facilities that are open or provided to the public lessen people with impairments' opportunities to equally and successfully engage in various everyday activities. In aiming to ensure equal access, and respect and dignity, accessibility has to be addressed in all its complexity, with physical environment, transportation, and provision of goods and services being linked together in a systematic and holistic way. The provision has to be founded on the assurance of equality and participation, rather than treated as a means to achieve strategic and capitalistic goals.

This was clearly opposite to the experiences of mystery shoppers with vision impairments, who constantly emphasised how certain accessibility provisions within the 'Blind district' and their absence or lack outside it, isolate their consumer experience within the neighbourhood and exclude from broader participation in the mainstream private market and society. Indeed, as Rolandas (male, 4I-64) argued, 'if similar provisions and practices were not only here [the 'Blind district'] but in the whole city, it would be different'. For people with vision impairments, then, accessibility provisions only in selected areas and environments and a failure to provide unrestricted chain of movement in the outside spaces and in-between them, create ghettoisation, social and consumer inequality, and marginalise their status in society and the market. They draw boundaries of the shopping 'map' and position some of the market players as 'no go' providers of good and services. In addition, the imbalance of and inconsistency in the accessibility provisions accentuate difference and separation between people with vision impairments, who live in the 'Blind district', and the rest of the population. This is very likely to strengthen power imbalances associated with the fact that non-disabled people are free to purchase from retailers in and outside the 'Blind district' whereas people with vision impairments' shopping are confined to the district. This may generate stigma and cement perceptions of difference and separateness.

The insights gleaned from the mystery shopping and consumer interviews suggest that fragmented accessibility provisions in built environment and public space have a negative impact on consumer mobility, choice and the extent to which freedom in the private market is exercised. In turn, this tailors the participants' loyalty to certain providers, and their values and attitudes ascribed to shopping. Being spatially segregated in the market, some people with vision impairments do not object paying more if this allows securing consumer independency and control over purchased items or services. As Hilda (female, age 65+) noted 'it is not cheap, but it is here'. This calls into question the awareness of retailers operating across the city of changes in and diversity of a potential clientele segment, and their initiative to attract different customers.

The participants' experiences also pointed out to double consumer exclusion. While a failure to approach accessibility of public space as a continuum in all its complexity restricts people's independency and equality compared to non-disabled individuals, improper maintenance of public environment creates additional forms of consumer exclusion. It was suggested that maintenance of public space founded on ablest 
assumptions converts accessible spaces into inaccessible and unusable and reinforce social and consumer exclusion of certain populations.

It was evident in the participants' narratives that accessibility of public space has a direct impact on how accessible the mainstream private market is to consumers who do not 'fit' conventional norms and standards. At the same time the broader discussion suggested that accessibility provisions per se neither resolve exclusion- and inequalityrelated experiences, nor create environments wherein people with impairments are not stigmatized but enjoy rights and opportunities that non-disabled individuals take for granted. Accessibility, indeed, has to be untied from its basic definition and technical standards, and approached in all its complexity. It has to consider links between different elements of and in public space, people's identities, feelings and emotions in the environment, and intend to create spaces that are accessible to and usable by all people despite their belonging to different administrative categories. However, creating public space that is accessible to everyone is hardly possible (Mace, 1988, Mace, 1998, Goldsmith, 20I I, Imrie, 2000, Imrie, 1996). Consequently, the adoption of a universalist approach aimed at the whole population in combination with group-targeted provisions is often seen as a means to ensure that spaces and artefacts are accessible to and usable by as many people as possible (Imrie, 20I3, Imrie and Hall, 200I, Mace, I988, 1998). Focusing on the 'Blind district' also suggested that responsible and sustainable planning and provision of accessibility should take into account the 'story' of a particular public space. Understanding the history of buildings, streets, monuments, transport infrastructure, and other elements as well as their relationship with other public spaces is important for developing environments that are friendly to people and aimed at their empowerment rather than control.

The interaction between population-targeted and group-targeted provisions, connectivity of the provisions, and the 'story' of public space impact accessibility of the public environment. This interaction has to be interpreted in light of changes in policy and population (Figure I). While the study introduced the significance of how these changes shape societal interactions and practices, more empirical research is needed to investigate the phenomenon in more detail.

This paper provided some insight into the under-researched issue of how public space shape accessibility of the mainstream private market to consumers who do not 'fit' conventional norms and standards, yet further investigation is needed.

Future research should address the way barriers and accessibility provisions on the way to shops shape disabled people's consumer identity and their consumerist lifestyle practices. We know precious little about the impact of public space on people with impairments' shopping habits, decision making and consumer agency. In addition, the paper suggested that when accessibility is provided in some geographical areas and not in others, people with impairments are likely to be excluded from free participation in the market and limited to providers that operate in accessible areas. Consequently, more investigation is needed into how group-targeted provisions in public space shape other aspects of disabled people's everyday life (romantic relationship, career choices, hobbies, civic participation, etc.) and their exercising of human rights. 


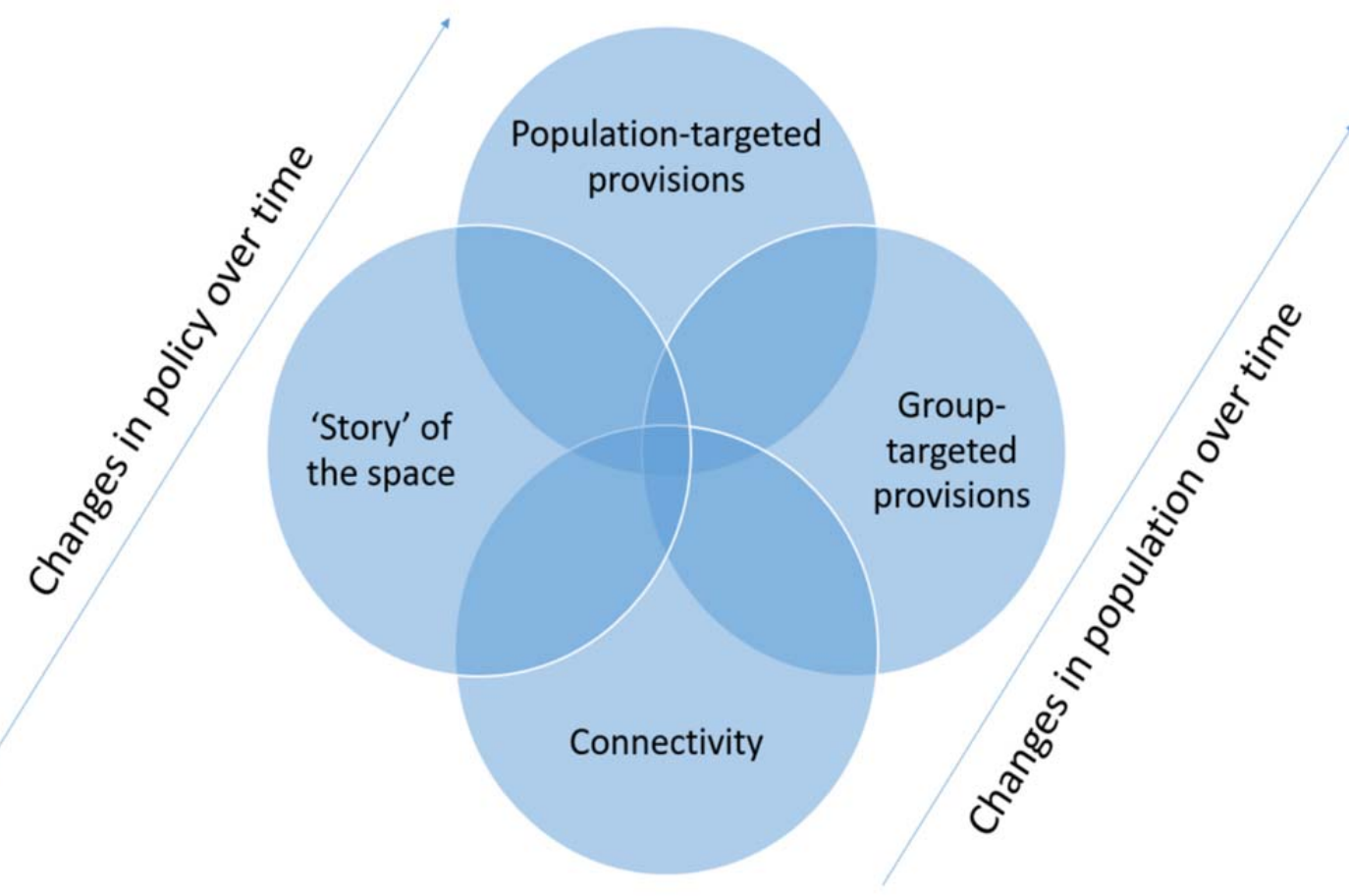

Figure I - Factors impacting accessibility of public space

\section{Acknowledgement}

This work was supported by the European Commission FP7, Marie Curie Initial Training Network (ITN); Project ID: 265057. The author would like to thank Professor Rob Imrie and Dr Gordon Clubb for their valuable comments on the ideas presented in the paper.

\section{References}

Abir, A. K. M. \& Hoque, M. S. (20I I). A study on mobility problem of disabled people in Dhaka city. Ist Civil Engineering Congress, December 22-24, Dhaka. Bangladesh Civil Engineering Division Institution of Engineers, p. I52-161.

Alexandrova, A., hamilton, E. \& kuznetsova, P. (2004). Housing and Public Services in a MediumSized Russian City: Case Study of Tomsk. Eurasian Geography and Economics, 45, II $14-133$.

Arksey, H. \& knight, P. T. (1999). Interviewing for social scientists: An introductory resource with examples, London, Sage.

Baker, J. \& Crompton, J. (2000). Quality, satisfaction and behaviour intentions. Ann Tour Res, 27, 758-804.

Baker, S. M. (2006). Consumer normalcy: Understanding the value of shopping through narratives of consumers with visual impairments. Journal of Retailing, 82, 37-50. 
Baker, S. M., holland, J. \& Kaufman-Scarborourgh, C. (2007). How consumers with disabilities perceive 'Welcome' in retail sercicescapes: A critical incident study. Journal of Services Marketing, 21, 160-173.

Baker, S. M., Stephens, D. L. \& Hill, R. P. (200I). Marketplace experiences of consumers with visual impairments: Beyond the Americans with Disabilities Act. Journal of Public Policy \& Marketing, 20, 215-224.

Barnes, C. \& Mercer, G. (1996). Exploring the Divide: Illness and Disability, Leeds, The Disability Press.

Barnes, C. \& Mercer, G. (2003). Disability, Cambridge, Polity Press.

Barnes, C. \& Mercer, G. (2005). Disability, work, and welfare: challenging the social exclusion of disabled people. Work, Employment \& Society, 19, 527-545.

Bashiti, A. \& Rahim, A. A. (2016). Physical Barriers Faced by People with Disabilities (PwDs) in Shopping Malls. Procedia - Social and Behavioral Sciences, 222, 4I 4-422.

Bauman, Z. (1988). Freedom, Milton Keynes: Open University Press.

Bauman, Z. (200I). Community. Seeking safety in an insecure world. Cambridge: Polity.

Beitel, D., Stipancic, J., Manaugh, K. \& Miranda-Moreno, L. (2018). Assessing safety of shared space using cyclist-pedestrian interactions and automated video conflict analysis. Transportation Research Part D: Transport and Environment, 65, 71 0-724.

Bertaud, A. \& Renaud, B. ( 1997). Socialist Cities without Land Markets. Journal of Urban Economics, 4I, |37-I5I.

Bertoli, M., Biasini, G., Calignano, M. T., Celani, G., De Grossi, G., Digilio, M. C., Fermariello, C. C., Loffredo, G., Luchino, F., Marchese, A., Mazotti, S., Menghi, B., Razzano, C., Tiano, C., Zambon Hobart, A., Zampino, G. \& Zuccalà, G. (20I I). Needs and challenges of daily life for people with Down syndrome residing in the city of Rome, Italy. Journal of Intellectual Disability Research, 55, 80 I-820.

Blackshaw, T. (20I3). How shopping changed leisure. Routledge Handbook of Leisure Studies. Routledge.

Borgers, A. \& Timmermans, H. (2205). Modelling pedestrian behaviour in downtown shopping areas. Proceedings of CUPUM conference London, CD-ROM paper.

Brown, B. B., Werner, C. M., Amburgey, J. W. \& Szalay, C. (2007). Walkable route perceptions and physical features: Converging evidence for en route walking experiences. Environment and Behavior, 39, 34-6I.

Brusdal, R. \& Lavik, R. (2008). Just shopping!:A closer look at youth and shopping in Norway. 16, 393-408.

Butler, R. \& Bowlby, S. (1997). Bodies and Spaces: An Exploration of Disabled People's Experiences of Public Space. 15, 4I I-433.

Campbell, C. (1997). Shopping, pleasure and the sex war. The shopping experience, I, I66-176.

Campbell, J. \& Oliver, M. (1996). Disability Politics. Understanding our Past, Changing our Future, London, Routledge.

Carrigan, M., Szmigin, I. \& Wright, J. (2004). Shopping for a better world? An interpretive study of the potential for ethical consumption within the older market. Journal of Consumer Marketing, 2I, 40I-4I7.

Černič Mali, B., Sendi, R., Boškić, R., Filipović, M., Goršič, N. \& Zaviršek Hudnik, D. (2003). Large Housing Estates in Slovenia, Overview of Developments and Problems in Ljubljana and Koper. Utrecht: Urban and Regional research centre Utrecht.

Chouinard, V. (1997). Making space for disabling differences: Challenging ableist geographies. Environment and Planning D: Society and Space, 15, 379-387.

Clapham, D. (1995). Privatisation and the East European Housing Model. Urban Studies, 32, 679694. 
Collins, J. C., Schneider, C. R., Faraj, R., Wilson, F., De Almeida Neto, A. C. \& Moles, R. J. J. I. J. O. C. P. (2017). Management of common ailments requiring referral in the pharmacy: a mystery shopping intervention study. 39, 697-703.

Crandall, W., Bentzen, B. L., Myers, L. \& Brabyn, J. (200I). New orientation and accessibility option for persons with visual impairment: Transportation applications for remote infrared audible signage. Clinical and Experimental Optometry, 84, I20-I3I.

Dangschat, J. (1987). Sociospatial disparities in a 'socialist' city: the case of Warsaw at the end of the 1970s. International Journal of Urban and Regional Research, II, 37-60.

Dunn, S. P. \& Dunn, E. (1989). Everyday life of people with disabilities in the USSR. In: McCagg, W. O. \& Siegelbaum, L. (eds.) People with disabilities in the Soviet Union; Past and present, theory and practice. Pittsburgh: University of Pittsburgh Press.

Eskytè, I. (2019). Disability and shopping: Customers, market and the state, New York, Routledge.

Eskytè, I. (20I5). Disabled shopping and urban design: Past and present. 'Unlocking' people with vision impairments' customer rights. Disability Research in Action: Disability Research and Disabled Realities. Leeds, United Kingdom.

Eskytè, I. (20/4). The 'Blind Area' of the city: Drawing shopping boundaries for people with vision impairments. Conference proceedings: Universal Design 2014: Three Days of Creativity and Diversity. Lund, Sweden.

Essa, M., Hussein, M. \& Sayed, T. (2018). Road users' behavior and safety analysis of pedestrianbike shared space: case study of Robson Street in Vancouver. Canadian Journal of Civil Engineering, 45, I053-1064.

Fänge, A., Iwarsson, S. \& Persson, A. (2002). Accessibility to the public environment as perceived by teenagers with functional limitations in a south Swedish town centre. Disability and Rehabilitation, 24, 318-326.

Fefolof, V. (1989). V SSSR involidov net! Overseas Publications Interchange Ltd.

Finkelstein, V. (1994). Getting there: Non-Disabling Transport. Therapy Weekly, March.

Fisher, J. C. (1962). Planning the City of Socialist Man. Journal of the American Institute of Planners, $28,25 \mid-265$.

Freund, P. (200I). Bodies, disability and spaces: The social model and disabling spatial organisations. Disability \& Society, 16, 689-706.

Freund, P. E. S. \& Martin, G. T. (1997). The automobile and transport policy. Policy Studies, I8, 269-283.

Friedrichs, J., Lüdtke, H., Derr, N. \& Gallasch, A. (1975). Participant observation: Theory and practice, Farnborough, Saxon House.

Goldsmith, S. (20I I). Designing for the disabled. The new paradigm, London, Routledge. Taylor \& Francis Group.

Graham, D. F., Graham, I. \& Maclean, M. J. (I99I). Going to the mall: A leisure activity of urban elderly people. Canadian Journal on Aging/La Revue canadienne du vieillissement, 10, 345-358.

Grava, S. (1993). The Urban Heritage of the Soviet Regime The Case of Riga, Latvia. Journal of the American Planning Association, 59, 9-30.

Gray, D. E. (2009). Doing research in the real world, London, Sage.

Grove, S. J. \& Fisk, R. P. (1992). Observational data collection methods for services marketing: An overview. Journal of the Academy of Marketing Science, 20, 217-224.

Guckian, M., De Young, R. \& Harbo, S. (2017). Beyond green consumerism: uncovering the motivations of green citizenship.

Guo, Z. (2009). Does the pedestrian environment affect the utility of walking? A case of path choice in downtown Boston. Transportation Research Part D: Transport and Environment, 14, 343-352.

Guo, Z. \& Ferreira, J. (2008). Pedestrian environments, transit path choice, and transfer penalties: Understanding land-use impacts on transit travel. Environment and Planning $B$ Planning and Design, 35, 46I-379. 
Guo, Z. \& Loo, B. P. Y. (20I3). Pedestrian environment and route choice: Evidence from New York City and Hong Kong. Journal of Transport Geography, 28, 124-I36.

Guthman, J., Brown, S. J. A. \& Values, H. (2016). I will never eat another strawberry again: the biopolitics of consumer-citizenship in the fight against methyl iodide in California. 33, 575585.

Hamilton-Baillie, B. J. U. D. I. (2008). Towards shared space. I3, I30-I38.

Hamilton, C. (2010). Consumerism, self-creation and prospects for a new ecological consciousness. Journal of Cleaner Production, 18, 57I-575.

Hanson, J. (2004). The inclusive city: Delivering a more accessible urban environment through inclusive design. Available: http://eprints.ucl.ac.uk/335I/I/335I.pdf [Accessed 25/04/20I3].

Hill, J. A. (20I I). Endangered childhoods: how consumerism is impacting child and youth identity. 33, 347-362.

Hoogendoorn, S. P. \& Bovy, P. H. L. (2004). Pedestrian route-choice and activity scheduling theory and models. Transportation Research Part B: Methodological, 38, 169-190.

Hughes, R. L. (2002). A continuum theory for the flow of pedestrians. Transportation Research Part B: Methodological, 36, 507-535.

Imrie, R. (1996). Disability and the city: International perspectives, London, Sage.

Imrie, R. (1998). Oppression, disability and access in the built environment. In: Shakespeare, T. (ed.) Disability reader: Social science perspectives. London: Continuum.

Imrie, R. (2000). Disabling environments and the geography of access policies and practices. Disability \& Society, 15, 5-24.

Imrie, R. (20I2). Auto-disabilities: The case of shared space environments. Environment and Planning-Part A, 44, 2260-2277.

Imrie, R. (2013). Designing inclusive environments and the significance of universal design. In: Swain, J., French, S., Barnes, C. \& Thomas, C. (eds.) Disabling Barriers-Enabling Environments. 2nd ed. London: Sage Publications.

Imrie, R. \& Hall, P. (200I). Inclusive design: Designing and developing accessible environments, London, Spon Press.

Imrie, R. \& Kumar, M. (1998). Focusing on disability and access in the built environment. Disability \& Society, 13, 357-374.

Imrie, R. F. \& Imrie, R. I. R. (1996). Disability and the city: International perspectives, Sage.

Ivanchenko, V., Coughlan, J. \& Shen, H. (20I0). Real-time walk light detection with a mobile phone. In: Miesenberger, K., Klaus, J., Zagler, W. \& Karshmer, A. (eds.) Computers Helping People with Special Needs. Berlin: Springer.

Jacob, S., Schiffino, N. \& Biard, B. (2018). The mystery shopper: a tool to measure public service delivery? 84, I64-I84.

Kaparias, I., Bell, M. G. H., Dong, W., Sastrawinata, A., Singh, A., Wang, X. \& Mount, B. (2013). Analysis of Pedestrian-Vehicle Traffic Conflicts in Street Designs with Elements of Shared Space. 2393, 21-30.

Karndacharuk, A., Wilson, D. J. \& Dunn, R. C. M. (20I3). Analysis of Pedestrian Performance in Shared-Space Environments. 2393, I-II.

Kaufman-Scarborough, C. (1999). Reasonable access for mobility-disabled persons is more than widening the door. Journal of Retailing, 75, 479-508.

Kaufman-Scarborough, C. (200I). Sharing the experience of mobility-disabled consumers: Building understanding through the use of ethnographic research methods. Journal of Contemporary Ethnography, 30, 430-464.

Kaufman-Scarborough, C. (2016). Social exclusion: a perspective on consumers with disabilities. In: Hamton, K., Dunnett, S. \& Piacentini, M. (eds.) Consumer Vulnerability: Conditions, contexts and characteristics. Oxon: Routledge.

Kehagias, J., Rigopoulou, I. \& Vassilikopoulou, A. (20I I). Linked mystery shopping inventory to customer-seller encounters. Journal of Customer Behaviour, 10, 7-34. 
Kishi, G. (1988). Daily decision-making in community residences: A social comparison of adults with and without mental retardation. American Journal of Mental Retardation, 92, 430-35.

Kitchin, R. O. B. (1998). 'Out of place', 'Knowing one's place': Space, power and the exclusion of disabled people. Disability \& Society, I3, 343-356.

Kostinskiy, G. (200I). Post-socialist cities in flux. In: Paddison, R. (ed.) Handbook of urban studies. London: sage.

Kulu, H. (2003). Housing differences in the late Soviet city: the case of Tartu, Estonia. International Journal of Urban and Regional Research, 27, 897-9II.

Ladanyi, J. (1993). Patterns of Residential Segregation and the Gypsy Minority in Budapest. International Journal of Urban and Regional Research, 17, 30-4I.

Lange, H. \& Meier, L. (2009). The new middle classes: globalizing lifestyles, consumerism and environmental concern, Springer Science \& Business Media.

Lass. n/a. LASS istorija [Online]. Available: http://www.lass.lt/index.php?4085/87250 [Accessed II/02/20I5].

Laws, G. (1994). Oppression, knowledge and the built environment. Political Geography, 13, 7-32.

Liu, C. H. (2015). How "quality" determines customer satisfaction. The TQM Journal, 27, 576590.

LRV (20I2). Pėsčiųju perejjų j̇rengimo taisyklès. In: Lietuvos Automobilių Kelių Direkcija Prie Susisiekimo Ministerijos (ed.) V-239. Vilnius.

Mace, R. (1988). Universal design: Housing for the lifespan of all people, Rockville, MD, US Department of Housing and Urban Development.

Mace, R. L. (1998). Universal design in housing. Assistive Technology, I0, 2I-28.

Madison, B. (1989). Programs for the disabled in the USSR. In: McCagg, W. O. \& Siegelbaum, L. (eds.) The Disabled in the Soviet Union : past and present, theory and practice. Pittsburgh: University of Pittsburgh Press.

Matthews, M. H. \& Vujakovic, P. (1995). Private worlds and public places: Mapping the environmental values of wheelchair users. Environment and Planning A, 27, I069-1083.

McClimens, A., Partridge, N. \& Sexton, E. (20I4). How do people with learning disability experience the city centre? A Sheffield case study. Health \& Place, 28, I4-2I.

Miller, N. J. \& Kim, S. (1999). The importance of older consumers to small business survival: Evidence from rural lowa. Journal of Small Business Management, 37, I-I 5.

Miller, N. J., Kim, S. \& Schofield-Tomschin, S. (1998). The effects of activity and aging on rural community living and consuming. Journal of Consumer Affairs, 32, 343-368.

Miller, R. (1998). Undercover shoppers. Marketing, I-4.

Miller, T. (2007). Cultural citizenship: Cosmopolitanism, consumerism, and television in a neoliberal age, Temple University Press.

Mittal, V. \& Kamakura, W. A. (200I). Satisfaction, repurchase intent, and repurchase behavior: Investigating the moderating effect of customer characteristics. Journal of Marketing Research, 38, $131-142$.

Moody, S. \& Melia, S. (20I4).Shared space: Research, policy and problems. Proceedings of the Institution of Civil Engineers-Transport, ICE, 384-392.

Morrall, K. (1994). Mystery shopping tests service and compliance. Bank Marketing, I3-23.

Morris, J. (1993). Independent lives: Community care and disabled people, Basingstoke, Palgrave Macmillan.

Morton, H. W. (1980). Who gets what, when and how? Housing in the Soviet Union. Soviet Studies, 32, 235-259.

Oliver, M. (1983). Social work with disabled people, London, Macmillan, for the British Association of Social Workers.

Oliver, M. (1990). The politics of disablement, New York, Palgrave Macmillan. 
Oliver, M. (1994). Capitalism, disability and ideology: A materialist critique of the normalization principle. Available: http://disability-studies.leeds.ac.uk/files/library/Oliver-cap-dis-ideol.pdf [Accessed 05/03/2012].

Oliver, M. (1996). Defining impairment and disability: Issues at stake. In: BARNES, C. \& MERCER, G. (eds.) Exploring the divide. Leeds: The Disability Press.

Oliver, M. (2009). Understanding Disability. From Theory to Practice, New York, Palgrave Macmillan.

Otieno, R., Harrow, C. \& Lea-Greenwood, G. (2005). The unhappy shopper, a retail experience: exploring fashion, fit and affordability. International Journal of Retail \& Distribution Management, 33, 298-309.

Patton, M. Q. (1990). Qualitative evaluation and research methods. 2nd ed., London, Sage Publications.

Permain, C. \& Roberts, S. (20I2). Marxist Planning in Little Moscow. Built and Natural Environment Research Papers, 5, 97.

Phillips, S. D. (2009). 'There are no invalids in the USSR!' A missing Soviet chapter in the new disability history. Disability Studies Quarterly [Online], 29. Available: http://www.dsqsds.org/article/view/936/IIII [Accessed 20/02/20I4].

Priestley, M., Jolly, D., Pearson, C., Riddell, S., Barnes, C. \& Mercer, G. (2007). Direct payments and disabled people in the UK: Supply, demand and devolution. British Journal of Social Work, 37, II 89-1204.

Relph, E. (1981). Rational landscapes and humanistic geography, London, Croom Helm.

Rosenberg, D. E., Huang, D. L., Simonovich, S. D. \& Belza, B. (20I2). Outdoor built environment barriers and facilitators to activity among midlife and older adults with mobility disabilities. The Gerontologist, 25, I- 12.

Sasnovy, T. (1959). The Soviet housing situation today. Soviet Studies, I I, I-2I.

Seneviratne, P. N. \& Morrall, J. F. (1985). Analysis of factors affecting the choice of route of pedestrians. Transportation Planning and Technology, 10, 147-I59.

Shakespeare, T. (1996). Rules of engagement: Doing disability research. Disability \& Society, II, $115-121$.

Stobart, J. (1998). Shopping streets as social space: leisure, consumerism and improvement in an eighteenth-century county town. Urban History, 25, 3-21.

Stolle, D., Hooghe, M. \& Micheletti, M. (2005). Politics in the Supermarket: Political Consumerism as a Form of Political Participation. 26, 245-269.

Temelová, J., Novák, J., Ouředníček, M. \& Puldová, P. (20II). Housing Estates in the Czech Republic after Socialism: Various Trajectories and Inner Differentiation. Urban Studies, 48, I8II-I834.

Thomas, M. J. (1978). City planning in Soviet Russia (1917-1932). Geoforum, 9, 269-277.

Tobis, D. (2000). Moving from residential institutions to community-based social services in Central and Eastern Europe and the Former Soviet Union, The World Bank.

Torres, I. M., Summers, T. A. \& Belleau, B. D. (200I). Men's shopping satisfaction and store preferences. Journal of Retailing and Consumer Services, 8, 205-21 2.

UPIAS (1976). Fundamental Principles of Disability, London, The Union of the Physically Impaired Against Segregation.

Varul, M. Z. (2015). Consumerism as Folk Religion: Transcendence, Probation and Dissatisfaction with Capitalism. 28, 447-460.

Vedagiri, P. \& Kadali, B. R. (2016). Evaluation of Pedestrian-Vehicle Conflict Severity at Unprotected Midblock Crosswalks in India. 258I, 48-56.

Wacquant, L. (1998). A black city within the white: revisiting America's dark ghetto. Black Renaissance, 2.I, I4I-I5I.

Wearing, S. L., McDonald, M. \& Wearing, M. (2013). Consumer culture, the mobilisation of the narcissistic self and adolescent deviant leisure. Leisure Studies, 32, 367-38I. 
Weinstein, A. A., Schlossberg, M. \& Irvin, K. (2008). How far, by which route and why? A spatial analysis of pedestrian preference. Journal of Urban Design, I3, 8I-98.

Wiele, T. V. D., Hesselink, M. \& Iwaarden, J. V. (2005). Mystery shopping: A tool to develop insight into customer service provision. Total Quality Management, 16, 529-54I.

Yaoyuneyong, G., Whaley, J. E., Butler, R. A., Williams, J. A., Jordan, K. L. \& Hunt, L. (20I8).

Resort mystery shopping: A case study of hotel service. Journal of Quality Assurance in Hospitality \& Tourism, 19, 358-386.

Yuksel, A. (2004). Shopping experience evaluation: A case of domestic and international visitors. Tourism Management, 25, 75I-759. 